\title{
Cash Waqf Linked Sukuk sebagai Instrumen Pemulihan Ekonomi Nasional Akibat Covid-19
}

DOI : $10.30595 /$ jhes.v\%vi\%i.10275

\section{${ }^{1}$ Eka Nur Baiti, ${ }^{2}$ Syufaat}

1IAIN Purwokerto, Email : ekanurbaiti13@gmail.com, syufaat@iainpurwokerto.ac.id

\begin{abstract}
Abstrak
Tulisan ini dimaksudkan untuk mengetahui peran Cash Waqf Linked Sukuk sebagai salah satu inovasi baru dari islamic social finance dalam membantu program pemulihan ekonomi nasional yang dilakukan oleh pemerintah di tengah pandemi COVID-19. Tulisan ini merupakan salah satu jenis penelitian kepustakaan dengan pendekatan kualitatif. Dari hasil penelitian diketahui bahwa peran Cash Waqf Linked Sukuk dalam membantu pemerintah memulihkan ekonomi nasional adalah bahwa hasil penjualan Cash Waqf Linked Sukuk ini dapat dijadikan sebagai sumber pembiayaan baru untuk pembangunan nasional dengan biaya yang murah, selain itu imbal hasil dari Cash Waqf Linked Sukuk ini dapat digunakan untuk program sosial yang ditujukan bagi masyarakat yang membutuhkan terutama masyarakat yang terdampak pandemi COVID-19.
\end{abstract}

Kata-kata kunci : Cash Waqf Linked Sukuk; Sukuk; Cash Waqf; Wakaf; CWLS.

\section{Abstract}

This paper written intended to find out the Cash Waqf Linked Sukuk role's as one of the new islamic social finance inovation in supporting National economic recovery which held by the government during the COVID-19 pandemic. This paper is done by using a library research and uses qualitatif methods. The research showed that the roles's of Cash Waqf Linked Sukuk in supporting The government doing the national economic recovery was by selling the Cash Waqf Linked Sukuk to be use as the new national financial resource of the national development with a minimum cost, and the Cash Waqf Linked Sukuk's coupon could be used as the covering fund for helping the pandemic affected people.

Keywords: Cash Waqf Linked Sukuk; Sukuk; Wakaf Uang; Waqf; CWLS. 


\section{Pendahuluan}

Munculnya virus baru jenis SARS-COV-2 pada penghujung tahun 2019 mengharuskan masyarakat menjaga diri agar tidak tertular virus, masyarakat harus menerapkan phiysical distancing bahkan banyak negara di dunia termasuk Indonesia melakukan lockdown untuk meminimalisir pergerakan masyarakat demi menghindari penularan virus ini. Kinerja ekonomi akibat pandemi ini menurun tajam, ekspor impor tertunda, investasi terhambat, konsumsi terganggu, sehingga pertumbuhan ekonomi sangat lambat bahkan menurun. Oleh karenanya pemerintah meluncurkan stimulus untuk membantu bangkitnya perekonomian Indonesia dengan mengeluarkan PP No 43 Tahun 2020 Tentang Program Pemulihan Ekonomi Nasional Dalam Rangka Mendukung Kebijakan Keuangan Negara Untuk Penanganan Pandemi COVID-19.(Kacaribu, 2020)

Sumber pendanaan program Pemulihan Ekonomi Nasional atau selanjutnya disebut dengan PEN seluruhnya adalah dari APBN. Total pengeluaran APBN untuk program PEN cukup fantastis yaitu mencapai Rp 677,20 Triliun (Kemenkeu RI, 2020). Dapat dikatakan bahwa pengalokasian APBN saat ini sangat difokuskan untuk penanganan dan penanggulangan COVID-19, oleh karenanya banyak pembangunan nasional yang tertunda akibat anggaran APBN yang terfokuskan pada penanganan COVID-19 ini. Pemerintah tentu memerlukan alternatif pembiayaan baru agar pembangunan nasional lain dapat terus berjalan.

Wakaf sebagai islamic social finance juga dapat dimanfaatkan untuk membantu program PEN ini, yaitu hadir sebagai sumber alternatif pembiayaan baru bagi pemerintah dalam melaksanakan pembangunan nasional. Hal ini dibuktikan dengan gencarnya Pemerintah menggalakkan aksi Gerakan Nasional Wakaf Uang (GNWU) untuk menggali potensi wakaf uang di Indonesia yang mencapai Rp 188 Triliun. Salah satu wujud pemerintah untuk mendukung GNWU dalam mengoptimalisasikan pengelolaan wakaf uang yaitu adanya Cash Waqf Linked Sukuk selanjutnya disebut CWLS. Dana yang dihasilkan dari CWLS ini diharapkan mampu menjadi salah satu sumber pembiayaan yang murah dalam pembangunan nasional. Return atau kupon hasil dari CWLS ini juga dapat digunakan sebagai dana sosial. CWLS ini 
sejatinya menggabungkan antara wakaf uang dengan instrumen pasar modal yaitu sukuk (obligasi syariah) yang diterbitkan oleh pemerintah (Permatasari, 2021) Lalu bagaimanakah mekanisme CWLS ini? Dan bagaimana CWLS membantu pemulihan ekonomi nasional? Hal ini akan dibahas lebih lanjut dalam makalah ini.

\section{Metode Penelitian}

Penelitian ini merupakan penelitian kepustakaan atau (library research) yaitu penelitian yang diperoleh dari sumber kepustakaan yaitu buku, laporan, makalah, artikel atau karya ilmiah lain yang mendukung penelitian ini. Penelitian ini menggunakan metode dokumentasi dalam pengumpulan data. Sumber data primer yang digunakan adalah Undang-Undang wakaf, Fatwa DSN-MUI tentang wakaf sukuk dan Peraturan Pemerintah tentang Program PEN. Sedangkan sumber data sekunder berasal dari artikel, hasil penelitian terdahulu, makalah, jurnal ilmiah dan buku-buku tentang wakaf produktif berupa uang khususnya yang membahas Cash Waqf Linked Sukuk.

Dalam menganalisis data yang diperoleh, penelitian ini menggunakan metode deskriptif. Analisis deskriptif adalah menafsirkan serta menyajikan data dengan sistematik agar lebih mudah dipahami dan disimpulkan. Kesimpulan diperoleh dengan jelas dasar faktualnya dan kembali langsung kepada data yang diperoleh (Bachtiar, 2018). Sedangkan analisis data kualitatif dalam hal ini adalah usaha yang dilakukan dengan bekerja dari data, pengorganisasian data,dan memilahnya menjadi satu kesatuan yang dapat dikelola, mensistensikan, mencari serta menemukan pola apa yang penting, apa yang dipelajari serta yang diperoleh kemudian memutuskan apa yang dapat diceritakan kepada orang lain.(Moleong, 2018)

\section{Hasil dan Pembahasan}

\section{Wakaf}

a. Pengertian Wakaf

Wakaf dalam kamus Bahasa Arab al-Munhij berasal dari kata (waqafayaqifu-waqfa) yang berarti berhenti, persamaannya adalah habasa atau 
(habasa-yahbisu-habsan wa mahbasa). Pada zaman Nabi SAW dan para sahabat dikenal dengan istilah habs, tasbil, atau tahrim (Dhewiyani, 2020). Menurut encyclopedia britania waqf is a pecualiarly islamic institution whereby the founder relingushes his ownership of real property, which belongs henceforth to Allah and dedicates the income or usufruct of the property in perpetuity to some pious or charitable purpose which may include settelments in favour of the founder's own family. (Rahman Ghazaly, Ihsan, \& Shidiq, 2012).

Menurut Sayyid Sabiq wakaf adalah menahan harta dan menggunakan manfaatnya di jalan Allah SWT. Sedangkan Taqiyuddin Abu Bakr bin Muhammad al-Husaeni menyebutkan bahwa wakaf adalah menahan harta yang kekal zatnya untuk diambil manfaatnya tanpa merusak zatnya yang manfaatnya dibelanjakan di jalan kebaikan dengan tujuan semakin dekat kepada Allah SWT. (Rahman Ghazaly et al., 2012). Atau secara umum wakaf adalah menahan harta yang bisa disalurkan kepada jalan yang diperbolehkan atau menahan benda yang tidak mudah rusak untuk diambil manfaatnya untuk kepentingan ummat sesuai ketentuan syara. Menurut UU No 41 Tahun 2004 Tentang Wakaf, pada pasal 1 disebutkan wakaf adalah perbuatan hukum wakif untuk memisahkan dan/atau menyerahkan sebagian harta benda miliknya untuk dimanfaatkan selamanya atau untuk jangka waktu tertentu sesuai dengan kepentingannya guna keperluan ibadah dan/atau kesejahteraan umum menurut syariah.('Undang-Undang Nomor 41 Tahun 2004 Tentang Wakaf', 2004)

Wakaf memiliki ciri mendasar yaitu wakaf tidak dapat dibatalkan, harta wakaf tidak bisa dicabut oleh pemberi atau ahli warisnya. Harta wakaf bersifat terus menerus. Artinya tidak dapat disita oleh pemerintah atau individu. Wakaf seperti harta yang dibekukan, oleh karenangya tidak dapat dijual, dibuang, digadaikan, dihadiahkan, diwarisi atau diasingkan dengan cara apapun.(Umar \& Aliyu, 2019)

b. Dasar Hukum Wakaf

1) Q.S Ali Imran : 92 


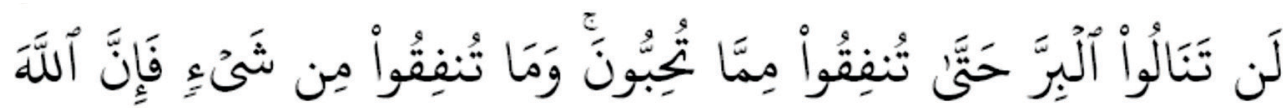

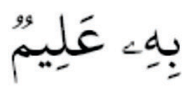

Artinya: Kamu sekali-kali tidak sampai kepada kebajikan (yang sempurna), sebelum kamu menafkahkan sehahagian harta yang kamu cintai. Dan apa saja yang kamu nafkahkan maka sesungguhnya Allah mengetahuinya.

2) Al-Baqarah : 267
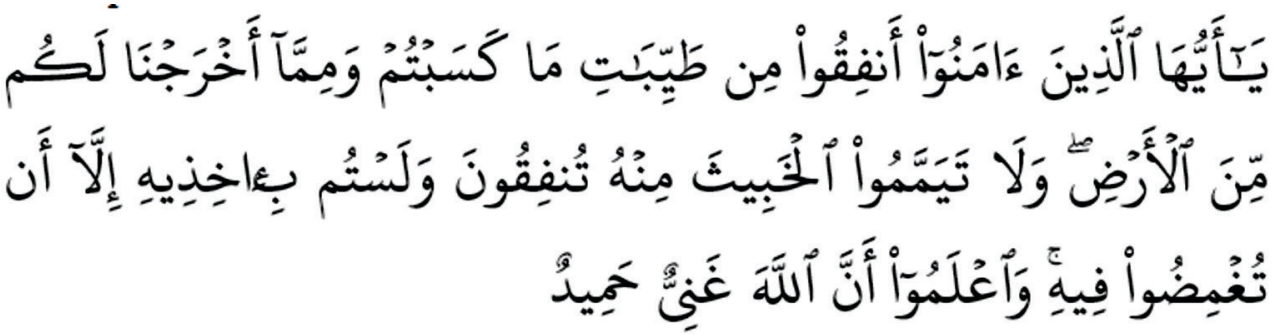

Artinya : Hai orang-orang yang beriman, nafkahkanlah (di jalan allah) sebagian dari hasil usahamu yang baik-baik dan sebagian dari apa yang Kami keluarkan dari bumi untuk kamu. Dan janganlah kamu memilih yang burukburuk lalu kamu menafkahkan daripadanya, padahal kamu sendiri tidak mau mengambilnya melainkan dengan memincingkan mata terhadapnya. Dan ketahuilah, bahwa Allah Maha Kaya lagi Maha Terpuji.

Ayat di atas secara umum memberi pengertian bahwa infak untuk tujuan kebaikan. Wakaf adalah menafkahkan harta untuk tujuan-tujuan kebaikan.

3) Sabda nabi Muhammad SAW dalam hadits:

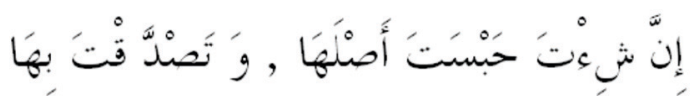

Artinya: "jika kamu ingin, kamu bisa menahan tanah itu, dan bersedekah dengan hasilnya".

4) Undang-Undang Nomor 41 Tahun 2004 Tentang Wakaf

5) Peraturan Pemerintah Nomor 42 tahun 2006 Tentang Pelaksanaan Undang-Undang No 41 Tahun 2004 Tentang Wakaf.

c. Rukun Wakaf dan Syarat-Syaratnya 
1) Adanya wakif. Syarat wakif antara lain wakif haruslah merdeka dan berakal sehat, wakif juga harus baligh, dan berilmu. Seorang wakif harus bebas untuk berbuat kebaikan dan berbuat atas kehendak sendiri.

2) Ada benda yang diwakafkan (maukuf), maukuf harus zat yang kekal zatnya dan dapat diambil manfaatnya, maukuf haruslah memiliki nilai atau berharga, maukuf haruslah benda milik wakif.

d. Nazhir

Nazhir berasal dari bahasa Arab yaitu nadzron-yandzhuru-nadzoro artinya mengurus atau mengatur. Nazhir adalah pengurus dapat berupa perseorangan maupun badan hukum yang diberikan amanat oleh pewakif untuk memelihara dan mengurus harta Wakaf sesuai dengan wujud dan tujuannya dan harus dilakukan dengan cara sebaik-baiknya. Syarat-syarat nazhir antara lain baligh, berakal sehat, mempunyai moral yang baik, jujur dan dapat dipercaya, serta memiliki kemampuan manajemen yang baik (Dhewiyani, 2020). Nazhir bertugas menjaga dan mengelola harta wakaf agar nilainya abadi dan tidak berkurang. Dalam bertugas nazhir harus berorientasi pada tujuan-tujuan wakaf.

e. Wakaf di Indonesia

Wakaf merupakan bagian dari hukum Islam. Wakaf telah diamalkan oleh muslimin sejak zaman nabi Muhammad SAW. Wakaf mulai dikenal sejak tahun kedua hijriyah. Pada tahun ke tiga hijriyah Rasulullah SAW mewakafkan tujuh kebun kurma di Madinah syariat wakaf pertama kali dilaksanakan oleh Umar bin Khattab yang mendapatkan tanah di khaibar. Kemudian sahabat menanyakan kepada nabi Muhammad dan beliau bersabda "kau tahan tanah itu dan engkau sedekahkan hasilnya, tidak dijual, tidak dihibahkan dan tidak diwariskan".Kemudian umar menyedekahkan hasil tanahnya kepada orang miskin, kerabat, hamba sahaya, sabilillah, ibnu sabil dan tamu dan tidak dilarang bagi pengelola waqaf makan dari hasilnya dengan cara baik atau sepantasnya atau memberi makan orang lain dengan maksud tidak menumpuk harta. (HR Imam Bukhori).

Di tahun 2018 tanah wakaf mencapai luas $4.952 .525 \mathrm{~m} 2$ di 335.300 lokasi, 121.046 diantaranya belum memiliki sertifikat wakaf dan 214.254 sudah bersertifikat wakaf (Fauziah \& Tulmafiroh, 2020). Di Indonesia 
$90 \%$ tanah wakaf hanya digunakan untuk makam, masjid, pesantren dan sekolah Islam. Padahal harta wakaf berpotensi digunakan sebagai aset yang lebih broduktif untuk kemaslahatan umat yang lebih besar. Oleh karenanya dibentuklah Badan Wakaf Indonesia (BWI) pada tahun 2007 tanggal 13 Juli dengan diterbitkannya Keppres No 75/M tahun 2007. BWI dihadirkan untuk membantu para nazhir untuk meningkatkan kemampuan dan ketrampilannya dalam mengelola wakaf agar aset-aset wakaf terkelola dengan profesional sehingga aset wakaf dapat bersifat produktif dan manfaatnya dapat segera dirasakan oleh masyarakat. BWI bertekad untuk mengelola aset wakaf tidak hanya dalam kepentingan ibadah saja, namun juga dalam bentuk pemberdayaan ekonomi, pelayanan sosial hingga pembangunan infrasutruktur publik.

Tujuan BWI atas pengelolaan aset wakaf sangatlah baik, namun masih banyak tantangan yang diperoleh dalam mengelola wakaf di Indonesia, salah satunya membangun mindset masyarakat untuk "melek wakaf". Kesadaran masyarakat Indonesia untuk menunaikan ibadah wakaf juga dinilai masih rendah. Oleh karenanya BWI banyak melaksanakan program edukasi dan sosialisasi wakaf uang untuk meningkatkan literaasi masyarakat. Perlu diketahui oleh masyarakat bahwa BWI mengelola wakaf dngan modern dan fleksibel, kelas pewakif juga tidak hanya orang tua saja tetapi menyasar ke kelas menengah dan para milenial. Menurut UU No 41 Tahun 2004 Tentang Wakaf, wakaf tidak hanya berbentuk benda tidak bergerak seperti tanah saja, namun dapat juga berbentuk barang bergerak seperti uang, saham, maupun berbagai macam instrumen surat berharga.

Masyarakat harus mengetahui bahwa wakaf bukan lagi tentang memberikan manfaat kepada muslimin saja, namun juga untuk seluruh ummat. Keberadaan wakaf jika pengelolaannya dilaksanakan dengan optimal, maka akan memberikan kontribusi luar biasa terhadap peningkatan ekonomi Indonesia. Mari bersama-sama wujudkan wakaf sebagai instrumen yang dapat turut serta membangun Indonesia dengan pengelolaan yang transparan, profesional, kredibel dan dapat dipercaya. 


\section{Sukuk atau Obligasi Syariah}

a. Pengertian Sukuk

Sukuk adalah akar kata dari Bahasa Arab "sakk", jamaknya "sukuk atau sakik" yang berarti "memukul atau membentur" dan bisa juga bermakna "pencetakan atau menempa" sehingga muncul kata kata "sakkan nukud" yang berarti "pencetakan atau penempahan uang"(Wahid, 2010). Katakata ini dugunakan secara luas oleh pengkaji Ekonomi Islam dan menjadi populer sebagai istilah untuk produk pengamanan aset atau disebut Islamic Bonds. Dalam buku Forward Lease Sukuk in Islamic Capital Markets, disebutkan bahwa Sukuk (Islamic Bonds) is defined as certificates of equal value representing ownership over an underlying asset. They prepresent common shares and rights over the underlying assets or over usufruct (benefits derived from an underlying asset) and services (Lahsana, Kabir Hassa, \& Ahmad, 2018).

Menurut Accounting and Auditing Organization for Islamic Financial Institution (AAOIFI) investasi sukuk merupakan sertifikat yang menempatkan kegunaan hak memiliki dengan nilai sama sebagai shares dan rights dalam aset tetap (tangible assets), manfaat (usufructs), dan pengkhidmatan (services) atau suatu kewajiban dari proyek atau investasi tertentu. (AAOIFI, 2003). Sukuk dalam dunia akademik juga dikenal sebagai Investment Certificates, investment trut certificates, sukuk securities, Islamic Bonds, dan Islamic Securities. Sukuk diidentifikasikan sebagai instrumen surat berharga yang menggunakan prinsip Hukum Islam atau syariah. (Al-Ali, 2019)

Sukuk berbeda dengan Obligasi (Bond), sukuk menunjukkan kepemilikan aset atu suatu proyek bisnis yang mendasarinya, sedangkan obligasi hanyalah bukti kewajiban hutang. Obligasi tidak mewakili kepemilikan yang hanya merupakan bukti hutang yang berbasis bunga yang akan diterima pemegang obligasi.(Nik Abdul Ghani, 2018). Dalam fatwa DSN MUI No 32/DSN-MUI/IX/2002 disebutkan “Obligasi Syariah adalah suatu surat berharga jangka panjang berdasarkan prinsip syariah yang dikeluarkan Emiten kepada pemegang Obligasi Syariah yang mewajibkan Emiten untuk membayar pendapatan kepada pemegang Obligasi Syariah berupa bagi hasil/ margin/ fee serta membayar kembali dana obligasi pada 
saat jatuh tempo."("Fatwa DSN- MUI No 32/DSN-MUI/IX/2002 Tentang Obligasi Syariah," 2002). Kemudian, MUI melakukan upgrading peraturan mengenai obligasi syariah menjadi sukuk dalam Fatwa DSN -MUI No 137/ DSN-MUI/IX/2020 dengan pengertian "Sukuk adalah Surat Berharga Syariah (Efek Syariah) berupa sertifikat atau bukti kepemilikan yang bernilai sama dan mewakili bagian kepemilikan yang tidak bisa ditentukan batas-batasnya (musya) atas aset yang mendasarinya (Aset Sukuk/ Usuhul al-Sukuk) setelah diterimanya dana sukuk, ditutupnya pemesanan dan dimulainya penggunaan dana seusuai peruntukannya."("Fatwa DSN -MUI No 137/DSN-MUI/IX/2020 Tentang Sukuk.," 2020)

Secara umum sukuk adalah produk investasi syariah yang menempatkan kegunaan hak memiliki shares dalam aset tetap (tangible assets), manfaat (usufructs) dan pengkhidmatan (services) atau suatu kewajaran dari proyek atau sesuatu bentuk investasi tertentu (Wahid, 2010). Sukuk juga disebut obligasi syariah yang merupakan efek syariah berupa sertifikat atau bukti kepemilikan yang bernilai sama dan mewakili bagian penyertaan yang tidak terpisahkan atau tidak terbagi atas kepemilikan aset berwujud tertentu, nilai manfaat dan jasa atas proyek tertentu atau nilai aktivitas investasi tertentu(Soemitra, 2009). Pada prinsipnya, sukuk hampir sama seperti obligasi konvensional. Perbedaan yang paling mendasar yaitu perbedaan penggunaan konsep atau istilah. Sukuk menggunakan istilah imbalan dan bagi hasil sedangkan obligasi konvensional menggunakan istilah bunga, dasar penerbitan sukuk adalah hadirnya suatu transaksi pendukung (underlying transaction) yang berbentuk sejumlah aset tertentu, serta penggunaan prinsip hukum Islam atau prinsip syariah pada sukuk agar terhindar dari riba, maysir dan gharar (Soemitra, 2009).

Obligasi adalah surat hutang yang memberikan hak berupa bunga kepada pemegang obligasi, sedangkan sukuk tidak memakai istilah hutang tetapi memakai istilah kewajiban yang akan muncul ketika terjadi transaksi atas aset/produk ataupun jasa tidak tunai, oleh karenanya terjadi transaksi pembiayaan. Sukuk lebih kepada penyerta modal dengan prinsip bagi hasil. Transaksinya tidak menggunakan akad utang-piutang melainkan penyertaan. Sukuk atau obligasi semacam ini biasa disebut 
muqaradhah bond, atau lebih dikenal dengan istilah mudharabah (Manan, 2016).

b. Landasan Hukum Sukuk

1) Al-Quran dalam surat Al-Baqarah ayat 275.
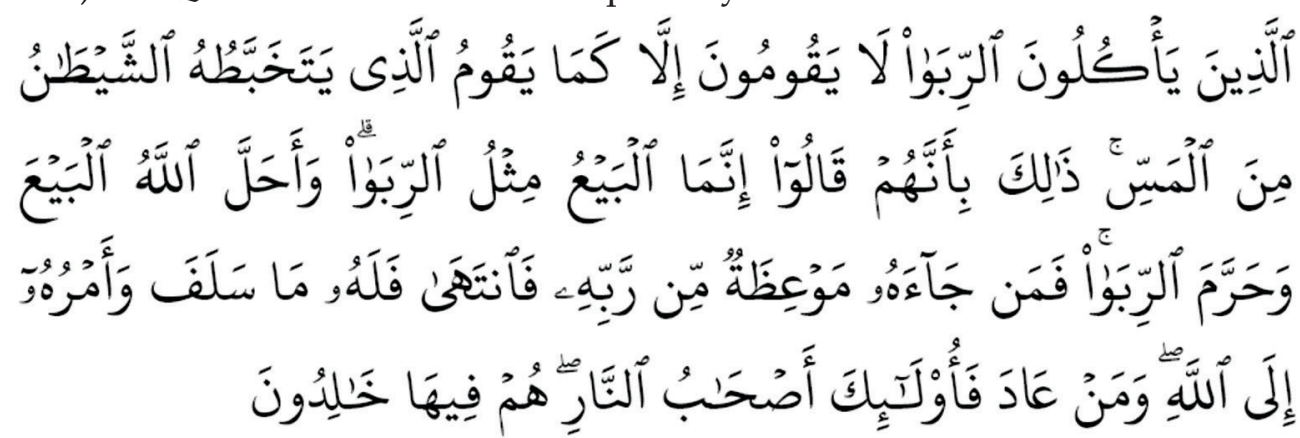

Artinya: Orang-orang yang makan (mengambil) riba tidak dapat berdiri melainkan seperti berdirinya orang yang kemasukan syaitan lantaran (tekanan) penyakit gila. Keadaan mereka yang demikian itu, adalah disebabkan mereka berkata (berpendapat), sesungguhnya jual beli itu sama dengan riba, padahal Allah telah menghalalkan jual beli dan mengharamkan riba. Orang-orang yang telah sampai kepadanya larangan dari Tuhannya, lalu terus berhenti (dari mengambil riba), maka baginya apa yang telah diambilnya dahulu (sebelum datang larangan); dan urusannya (terserah) kepada Allah. Orang yang kembali (mengambil riba), maka orang itu adalah penghuni-penghuni neraka; mereka kekal di dalamnya.

2) Hadis Qudsi riwayat Abu Dawud al-Daruquthni dan al-Hakim dari Abu Hurairah Rasulullah SAW berkata:

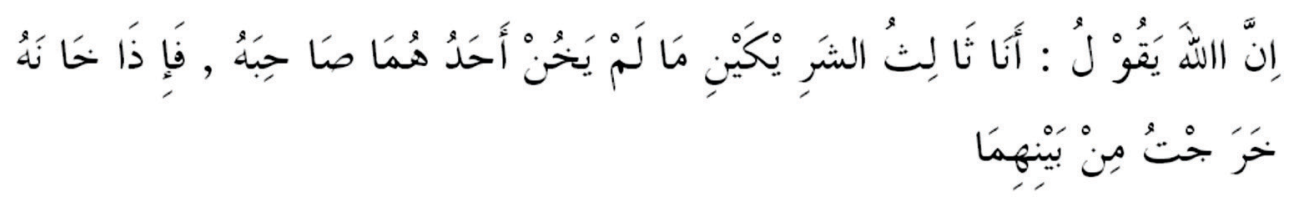

Artinya: Allah SWT berfirman: "Aku adalah pihak ketiga dari dua orang yang berkongsi selama salah satu pihak tidak mengkhianati pihak yang lain. Jika salah satu pihak telah berkhianat aku keluar dari mereka."

3) Kaidah Fiqh 


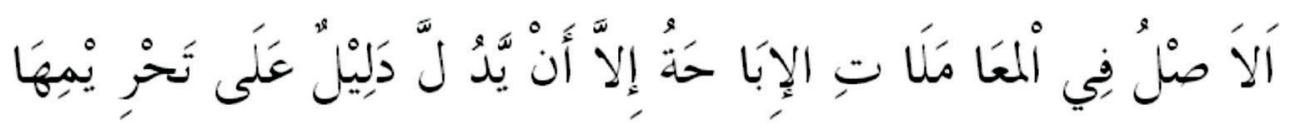

Artinya: "pada dasarnya, segala bentuk muamalat adalah boleh kecuali ada dalil yang mengharamkannya"

4) Landasan Sukuk dalam Hukum Positif

a) Undang-Undang Nomor 8 Tahun 1995 tentang Pasar Modal.

b) Peraturan Otoritas Jasa Keuangan Nomor 18/POJK.04/2015 Tentang Penerbitan dan Persyaratan Sukuk.

c) Fatwa DSN-MUI No 32/DSN-MUI/IX/2002 Tentang Obligasi Syariah.

d) Fatwa DSN-MUI No 33/DSN-MUI/IX/2002 tentang Obligasi Syariah Mudharabah.

e) Fatwa DSN-MUI No 137/DSN-MUI/IX/2020 Tentang Sukuk.

\section{Surat Berharga Syariah Negara (SBSN)}

SBSN disebut juga sebagai Sukuk Negara. Sukuk Negara adalah surat berharga negara yang diterbitkan berdasarkan prinsip syariah sebagai bukti atas bagian penyertaan terhadap aset SBSN, baik dalam mata uang rupiah maupun valuta asing (Soemitra, 2009).

a. SBSN memiliki karakteristik:

1) Sebagai bukti kepemilikan suatu aset berwujud atau hak manfaat (beneficial title), pendapatan berupa imbalan (kupon), margin dan bagi hasil sesuai dengan bentuk akad saat perjanjian.

2) Terbebas dari hal-hal yang dilarang oleh prinsip syariah yaitu riba, gharar dan maysir

3) Penerbitan lewat wali amanat berupa special purpose vehicle (SPV)

4) Memerlukan underlying asset (sejumlah tertentu aset yang akan menjadi objek perjanjian) (Soemitra, 2009).

b. SBSN memiliki tujuan:

1) Memberikan solusi alternatif baru sumber pembiayaan negara

2) Turut mengembangkan pasar keuangan syariah

3) Menciptakan benchmark baru di pasar keuangan syariah 
4) Sukuk merupakan produk baru, sehingga akan meningkatkan jumlah penjualan bagi investor

5) Mengembangkan alternatif instrumen investasi

6) Mengoptimalkan pemanfaatan barang milik negara

7) Memanfaatkan dana-dana masyarakat yang belum masuk atau belum mendapatkan layanan sistem keuangan konvensional (Soemitra, 2009).

c. Akad dalam Cash Waqf Linked Sukuk

CWLS masuk ke dalam salah satu instrumen Surat Berharga Syariah Negara (SBSN). Akad CWLS menggunakan akad sukuk yang telah mendapatkan fatwa dari DSN MUI yaitu dapat menggunakan akad Ijarah, Ishtisna, dan Wakalah.(Saptono, Husna, \& Tanjung, 2021)

1) Sukuk Istishna

Dalam buku yang berjudul Sukuk Securities New Ways of Debt Contracting disebutkan bahwa Istisna is a contract a manufactured product, is the proper method of financing working capital in the manufacturing and construction sectors. Istisna allows one party to obtain industrial goods with either advance cash payment and deferred delivery of deffered payment and delivery. The costreduction benefit for the issuer is in the term that all or part of the working capital is obtained from external resources; consequently the final product is manufactured at a lower cos(Safari, Ariff, \& Mohamad, 2019). Dalam pemahaman ekonomi, sukuk istishna adalah zero coupon non-tradable sukuk, dalam hal ini issuer harus menentukan aset yang akan dijadikan jaminan (contoh: kontraktor mendapat proyek pembangunan), setelah pembangunanselesai, aset akan dijual kepada konsumen kemudian hasil keuntungan penjualan akan dibagikan juga kepada pemegang sukuk ishtisna. Hal ini berlaku baik dalam kontrak jual beli tunai maupun kontrak jual beli non tunai (Safari et al., 2019).

2) Sukuk Ijarah

Sukuk Ijarah adalah salah satu jenis sekuritas di pasar modal yang mewakili kepemilikan suatu aset yang telah ditentukan dan diketahui bersama dengan jelas, yang melekat pada suatu kontrak sewa beli (lease), kemudian pembayaran sewa akan diberikan kepada pemegang sukuk 
atau investor (Manan, 2016). Dalam konteks sukuk ijarah, penerbit sukuk akan menjual asetnya kepada investor atau pemegang sukuk, artinya kepemilikan aset dialihkan dari penerbit sukuk ke investor atau pemegang sukuk. Menurut Al-Amin karakteristik sukuk ada empat, yaitu:

a) Surat berharga yang mewakili kepemilikan suatu aset yang sudah jelas keberadaannya dimana hal tersebut telah terikat kontrak sewa.

b) Beberapa sukuk ijarah mungkin tidak mendapatkan laba bersih karena harus dikurangi dengan biaya pemeliharaan dan biaya asuransi yang ditentukan sebelumnya.

c) Sukuk ijarah dapat diperdagangkan di pasar sekunder.

d) Sukuk ijarah menawarkan tingkat fleksibilitas tinggi dari segi manajemen penerbitan dan pemasarannya (Nahar, Adha, \& Wardani, 2018).

Sukuk ijarah merupakan salah satu sukuk yang memberikan kontribusi paling besar dalam meningkatkan perekonomian. Sukuk Ijarah ini adalah sukuk yang paling banyak diterima oleh para ulama dan yang paling populer diterapkan dalam proyek pembiayaan. (Nahar et al., 2018)

3) Sukuk Wakalah

Sukuk Wakalah atau SBSN wakalah dalam Fatwa DSN MUI Nomor 95/ DSN-MUI/VII/2014 Tentang SBSN Wakalah disebutkan bahwa SBSN Wakalah adalah SBSN wakalah bil istitsmar yaitu SBSN yang diterbitkan berdasarkan prinsip syariah sebagai bukti kepemilikan atas bagian dari aset dalam kegiatan investasi yang dikelola oleh Perusahaan Penerbit SBSN selaku Wakil dari pemegang SBSN. Ketentuan khusus SBSN Wakalah dalam Fatwa DSN MUI Nomor 95/DSN-MUI/VII/2014 Tentang SBSN Wakalah:

a) Penerbitan SBSN dapat dilaksanakan secara langsung oleh Pemerintah atau melalui Perusahaan penerbit SBSN

b) Penerbit SBSN wajib menyatakan bahwa dirinya bertindak sebagai Wali Amanat/ Wakil dari pemegang SBSN untuk mengelola dana 
hasil penerbitan SBSN dalam berbagai kegiatan yang menghasilkan keuntungan

c) Penerbit SBSN wajin menerbitkan SBSN Wakalah

d) Penerbit SBSN sebagai Wakil dapat menjamin dana investor

e) Penerbit SBSN sebagai Wakil dalam pengelolaan dana hasil penerbitan SBSN wajib:

(1) Menyampaikan kepada calon investor rencana penggunaan dana

(2) Menyampaikan jenis akad wakalah yang digunakan

(3) Menggunakan dana tersebut dalam berbagai kegiatan apa saja

(4) Menjaga komposisi kegiatan penggunaan sebagian besar dana

(5) Menginformasikan penggunaan dana dalam kegiatan yang dilakukannya

(6) Menginformasikan apabila terjadi perbedaan pelaporan antara realisasi penggunaan dana dengan rencana yang telah disampaikan

(7) Menyerahkan sepenuhnya keuntungan yang diperoleh kepada pemegang SBSN secara periodik atau saat jatuh tempo

(8) Menjelaskan dan mendapat opini syariah jika terjadi penggunaan dana yang diragukan kepatuhan syariahnya.

f) Dalam melakukan kegiatannya penerbit SBSN:

(1) Dapat melakukan transasksi dengan pemerintah atau pihak lain

(2) Dapat memberikan kuasa kepada pemerintah atau pihak lain yang ditunjuk dalam rangka pengadaan atau pengelolaan Aset SBSN

(3) Wajib memperhatikan substansi dari Fatwa DSN yang terkait dengan akad-akad dalam melakukan invetasi

(4) Dapat menerima ujrah dalam hal wakalah dilakukan dengan akad wakalah bil ujrah.

g) Pemerintah dapat membeli sebagian atau seluruh aset SBSN wakalah sebelum jatuh tempo dengan membayar harga sesuai kesepakatan. 
h) Untuk pembelian aset SBSN wakalah sebelum jatuh tempo, para pihak melakukan perubahan atau pengakhiran akad SBSN Wakalah.(“Fatwa DSN MUI No 95/DSN-MUI/VII/2014 Tentang SBSN Wakalah," 2014)

Saat ini CWLS menggunakan akad sukuk wakalah, ini dikarenakan sukuk wakalah memiliki fleksibilitas dalam penggunaan underlying asset. Adapun underlying asset yang dapat digunakan dalam penerbitan SBSN Wakalah dapat berupa kombinasi dari beberapa jenis aset, baik aset berwujud maupun aset tidak berwujud. Yaitu dapat berupa barang, jasa, proyek atau aset lainnya yang sesuai dengan prinsip syariah.(Saptono et al., 2021)

\section{Pemulihan Ekonomi Nasional}

Pandemi COVID-19 memberikan efek ganda dan luar biasa pada seluruh aspek antara lain aspek kesehatan, sosial, ekonomi, dan keuangan. Di sektor kesehatan penyebaran virus COVID-19 yang sangat cepat dan luas menimbulkan krisis kesehatan karena belum ditemukan vaksin kemudian disusul dengan keterbatasan alat serta tenaga medis. Cepat dan luasnya penularan virus ini memberikan dampak pada berkurangnya aktivitas ekonomi yang menyerap tenaga kerja di berbagai sektor. Pada sektor ekonomi, kinerja ekonomi menurun tajam, konsumsi terganggu, investasi terhambat, ekspor-impor tertunda membuat pertumbuhan ekonomi menurun tajam. Disusul di sektor keuangan banyak investor menjual atau mengurangi jumlah investasinya. Disamping itu sektor keuangan juga terdampak yaitu menurunnya peforma sektor riil dimana NPL (Non Performing Loan) atau kualitas kredit yang buruk, menurunnya profitabilitas (kempuan memperoleh laba) dan solvabilitas (kemampuan perusahaan memenuhi kewajiban/ hutang) (Kacaribu, 2020) .

Pandemi menyebabkan krisis yang luar biasa, pertumbuhan ekonomi Indonesia dipastikan menurun dibandingkan tahun 2019. Akibatnya terjadi PHK dimana mana dan meningkatkan angka pengangguran serta memperparah kemiskinan. Permintaan (demand) menurun drastis akibat hilangnya pendapatan masyarakat akibat COVID-19. Selain itu permintaan menurun diakibatkan adanya kebijakan phisycal distancing yang mengharuskan 
masyarakat menetap di rumah, hal ini menyebabkan berkurangnya permintaan. Berkurangnya permintaan akan mengakibatkan menurunnya produksi. Hal ini bahkan diperparah dengan adanya lockdown di berbagai negara sehingga menghambat ekspor dan impor untuk memenuhi kebutuhan masyarakat. Dapat dilihat semua sektor ekonomi terguncang akibat pandemi COVID -19. Krisis ini bahkan merambah ke sektor riil ekonomi seperti perbankan, rumah tangga, UMKM, dan banyak usaha yang tutup sehingga mengakibatkan banyak pelaku usaha tidak bisa membayar hutang dan peningkatan permohonan restrukturisasi. Pemerintah meluncurkan stimulus fiskal untuk membantu bangkitnya ekonomi nasional yang disebut dengan Program Pemulihan Ekonomi Nasional dan diwujudkan dalam PP No 43 Tahun 2020 Tentang Pelaksanaan Program Pemulihan Ekonomi Nasional Dalam Rangka Mendukung Kebijakan Keuangan Negara Untuk Penanganan Pandemi Corona Virus Disease 2019 (COVID-19) dan/atau Menghadapi Ancaman yang Membahayakan Perekonomian Nasional dan/atau Stabilitas Sistem Keuangan Serta Penyelamatan Ekonomi Nasional. Menurut pasal 1 ayat 1 PP No 43 Tahun 2020:

(1)Program Pemulihan Ekonomi Nasional yang selanjutnya disebut Program PEN adalah rangkaian kegiatan untuk pemulihan perekonomian nasional yang merupakan bagian dari kebijakan keuangan nefara yang dilaksanakan oleh Pemerintah untuk mempercepat penanganan pandemi Corona Virus Disease 2019 (COVID-19) dan/ atau menghadapi ancaman yang membahayakan perekonomian nasional dan/ataustabilitas sistem keuangan sertapenyelamanatan ekonomi nasional.

Dukungan pemerintah untuk memulihkan ekonomi nasional dilakukan pada dua sisi yaitu:

a. Sisi Permintaan (demand)

Pada sisi ini pemerintah fokus pada 3 hal yaitu menjaga konsumsi, mendorong investasi serta mendukung ekspor dan impor. Untuk menjaga konsumsi program yang dilakukan oleh antara lain pemberian $\mathrm{PKH}$, bantuan sembako gratis, pembebasan biaya listrik, Bansos, Bantuan Langsung Tunai, dan kartu prakerja. Untuk mendorong investasi pemerintah meluncurkan program insentif di bidang perpajakan termasuk insentif bea dan cukai, pemberian kelonggaran pengajuan kredit 
modal kerja bagi UMKM dan keringanan pembayaran. Sedangkan untuk mendukung ekspor dan impor pemerintah melakukan penyederhanaan dan pengurangan larangan pembatasan ekspor dan impor, mempercepat proses ekspor impor bagi trader yang bereputasi baik serta meningkatkan layanan ekspor impor dalam hal pelayanan melalui National Logistic Ecosystem (Kacaribu, 2020).

b. Sisi Penawaran (Supply)

Program yang dilakukan pada sisi penawaran (Supply) diberikan kepada dunia usaha yaitu:

1) Untuk UMKM yaitu pemberian subsidi bunga, Insentif perpajakan, penjaminan untuk kredit modal kerja untuk UMKM.

2) Untuk BUMN yaitu penyertaan modal negara (PMN), pembayaran kompensasi, talangan (investasi) modal kerja, dan dukungan dalam bentuk lain seperti optimalisasi Barang Milik Negara, Pelunasan tagihan, loss limit penjaminan, penundaan dividen, penjaminan pemerintah, pembayaran talangan tanah proyek strategis nasional (PSN).

3) Untuk Korporasi yaitu pemerian insentif perpajakan dunia usaha, penempatan dana pemerintah dan restrukturisasi debitur UMKM (Kacaribu, 2020).

Prinsip yang pemerintah terapkan dalam meluncurkan Program Pemulihan Ekonomi Nasional (PEN):

1) Asas keadilan sosial dan sebesar-besarnya kemakmuran rakyat

2) Mendukung para pelaku usaha yang terdampak pandemi COVID-19

3) Memperhatikan kaidah-kaidah kebijakan yang prudent serta tata kelola/ Good Corporate Governance yang baik, transparan, akseleratif, adil dan akuntabel sesuai dengan ketentuan

4) Tidak menimbulkan moral hazard yang menimbulkan kerugian

5) Adanya pembagian biaya dan risiko antar stakeholders sesuai tugas dan kewenangan masing-masing (Kacaribu, 2020).

Total APBN yang dianggarkan pemerintah untuk mendukung keberhasilan Program Pemulihan Ekonomi Nasional adalah Rp 695,20 Triliun. Anggaran 
ini antara lain untuk:

1) Anggaran Belanja Negara Rp 149,1 $\mathrm{T}$ untuk dukungan konsumsi seperti bansos dan subsidi, Rp 72,6 T untuk dukungan pajak/ insentif perpajakan, Rp 39,2 T untuk subsidi bunga kredit dan pembayaran kompensasi.

2) Pembiayaan. Penyertaan modal negara (PNM), penempatan dana pemerintah untuk perbankan yang memberikan kebijakan restrukturisasi sebesar Rp $35 \mathrm{~T}$, penjaminan kredit modal kerja senilai Rp $1 \mathrm{~T}$ dan untuk talangan investasi BUMN sebagai modal kerja

3) Tambahan belanja Kementerian atau Lembaga \& Sektoral. Dalam hal ini pemerintah menganggarkan sebesar Rp 30,1 T dimana Rp 3,8 T untuk sektor pariwisata yaitu pemberian diskon pesawat, destinasi wisata dan insentif pajak bagi hotel dan restoran. Kemudian Rp 1,3 T diberikan untuk sektor perumahan yaitu subsidi bunga dan bantuan uang muka KPR dan Rp $25 \mathrm{~T}$ sisanya yaitu stimulus untuk penguatan dukungan sektor pariwisata.

4) Dukungan untuk Pemda sekurangnya yaitu diberikan untuk pemanfaatan Dana Alokasi Khusus (DAK) fisik untuk pembangunan, kompensasi pembebasan pajak hotel dan restoran, penyediaan tambahan Dana Insentif Daerah untuk pemulihan ekonomi dan penyediaan fasilitas program pinjaman (Pemerintah Republik Indonesia, 2020)

\section{Cash Waqf Linked Sukuk di Indonesia}

Untuk mengelola wakaf non produktif menjadi non produktif diperlukan dana yang tidak sedikit, oleh karenanya diperlukan alternatif pendanaan melalui pasar keuangan syariah yaitu sukuk. Dalam hal ini penerbit sukuk adalah pemerintah melalui kementerian keuangan dengan seri SWR001. Cash Waqf Linked Sukuk adalah program wakaf uang berjangka hasil kolaborasi dan inovasi di bidang keuangan serta investasi sosial Islam di Indonesia. Dikembangkan untuk mendukung pasar keuangan syariah menghimpun dana sosial islam dan mendorong ragam bisnis bank syariah serta ragam instrumen SBSN. (Direktorat Pembiayaan Syariah, Direktorat Jenderal 
Pengelolaan Pembiayaan dan Risiko, Kementerian Keuangan Republik Indonesia, 2020)

Sukuk yang diintegrasikan dengan wakaf berpotensi memberikan suntikan agar aset-aset wakaf bersifat produktif. Sukuk berperan sebagai instrumen untuk memobilisasi sedangkan wakaf memiliki kapasitas dalam mendapatkan income dana aktifitas keuangan yang produktif. Inovasi ini menyediakan pembiayaan dalam rangka pembangunan ekonomi berkelanjutan.. Melalui sukuk wakaf, pemerintah menfasilitasi para pewakaf uang untuk menempatkan wakaf uangnya pada instrumen investasi yang aman dan produktif. Wakaf uang yang terkumpul dikelola dan ditempatkan oleh nazhir pada instrumen SBSN yang diterbitkan oleh pemerintah melalui Kementerian Keuangan. Kemudian imbal hasil sukuk atau kupon sukuk akan digunakan untuk kegiatan dan pembangunan proyek sosial produktif yang akan menjadi aset wakaf. Untuk wakaf uang temporer saat jatuh tempo uang akan dikembalikan 100\% kepada wakif. Seri pertama menggunakan seri Private Placement dengan ketentuan wakif melalui institusi nazhir, produk dengan tenor 3-5 tahun (jangka panjang), minimal order 50 Miliar dan non tradable. Kini melalui sukuk wakaf ritel atau terbuka, target wakif tidak hanya institusi, namun juga individu. Tenor produknya hanya 2 tahun dengan minimal order hanya 1 juta rupiah. CWLS Ritel ini bertujuan agar lebih banyak masyarakat yang ikut berpartisipasi dalam perwakafan di Indonesia.

\section{Urgensi Penerbitan Cash Waqf Link Sukuk}

Pemerintah melalui Kementerian Keuangan menyebutkan urgensi penerbitan CWLS antara lain untuk:

a. Penguatan Kapasitas Ekonomi Keuangan Syariah. Adanya CWLS memberikan kontribusi terhadap pengembangan ekonomi syariah di Indonesia. Ini menunjukkan bahwa cakupan atau kapasitas ekonomi syariah memang luas dan dapat mewujudkan kontribusi dalam pembangunan nasional.

b. Penguatan Institusional Pengelolaan Wakaf Nasional. Adanya CWLS memberikan kegiatan atau inovasi baru dalam mengembangkan pengelolaan wakaf di Indonesia. CWLS diharapkan mampu meningkatkan 
pengumpulan dana wakaf dan menjadikannya lebih produktif untuk kepentingan umat.

c. Dukungan Pencapaian SDG's . SDG's adalah Sustainable Development Goals yang merupakan suatu rencana aksi global yang disepakati oleh pemimpin dunia guna menghentikan kemiskinan dan mengakhiri kesenjangan serta mengoptimalkan perlindungan terhadap lingkungan. Hasil dari CWLS dapat digunakan sebagai kegiatan sosial dan pembangunan aset wakaf untuk kepentingan umat yang otomatis dapat meningkatkan pencapaian SDG's di Indonesia.

d. Pengembangan Investasi Sosial pada Masa Pandemi. Dalam kegiatan ekonomi syariah, selain Islamic Comercial Finance juga dikenal Islamic Sosial Finance yang didalamnya termasuk wakaf. Pengembangan CWLS ini menunjukkan bahwa selain investasi akhirat, wakaf juga dapat dijadikan salah satu investasi sosial kepada masyarakat yang membutuhkan, terutama mereka yang terdampak pandemi COVID-19 ini, yang memberikan banyak efek negatif terhadap perekonomian masyarakat. Hadirnya CWLS diharapkan mampu membantu pemulihan ekonomi umat di tengah pandemi COVID-19.

\section{Stakeholder Cash Waqf Link Sukuk}

a. Bank Indonesia, sebagai akselerator dalam mendorong implementasi CWLS dan Bank Kustodian.

b. BWI (Badan Wakaf Indonesia) sebagai regulator, leader, dan nazhir yang mengelola CWLS.

c. Kementerian Keuangan yang mewakili pemerintah, sebagai issuer SBSN dan pengelolaan dana sektor riil.

d. Nazhir Wakaf Produktif yang bermitra dengan BWIbertugas melakukan pengelolaan dan penyaluran hasil wakaf kepada mauquf alaih.

e. Bank kustodian (BNI Syariah, Bank Syariah Mandiri, Bank Muamalat, Bank BRI Syariah) sebagai lembaga keuangan syariah penerima wakaf uang (LKS-PWU) dan Bank Operasional BWI. Potensi CWLS tidak hanya berasal dari masyarakat namun Bank Umum Syariah yang sekaligus sebagai LKS-PWU juga sekaligus dapat menjadi pewakif 
yaitu lewat dana yang dikelola ataupun alokasi dana sosial dengan cara menggunakan dana CSR untuk ditempatkan pada CWLS, atau secara bilateral melaui BUS/UUS dengan bank induk mendapatkan dana untuk ditempatkan di CWLS, dan dari sisi aset, BUS dapat menempatkan dana pada CWLS sebagai alternatif alokasi ekses likuiditas BUS (Nezliani, 2020).

\section{Sifat Cash Waqf Link Sukuk}

a. Aman, maksudnya adalah bahwa CWLS seluruhnya dijamin oleh negara, tidak akan terjadi resiko gagal bayar saat jatuh tempo (bagi temporary wakaf).

b. Produktif, dikatakan produktif karena CWLS menghasilkan imbal hasil yang dapat digunakan untuk kegiatan sosial.

c. Optimal, disebut optimal karena imbal hasil yang dihasilkan CWLS kompetitif dan tidak dipotong pajak.

d. Berkah karena selain imbal hasil sukuknya disalurkan ke mauquf alaih, pewakif juga mendapatkan pahala atau kebaikan akhirat berupa amal jariyah.

e. Kesejahteraan ekonomi dalam masyarakat. Imbal hasil dari CWLS akan disalurkan untuk kepentingan sosial atau kesejahteraan umat.

\section{Mekanisme Cash Waqf Link Sukuk}

CWLS launcing pada tanggal 09 Oktober 2020 dengan masa penawaran mulai tanggal 9 Oktober 2020 pukul 09.00 WIB sampai dengan 12 November 2020 kemudian diperpanjang hingga 20 November 2020. Penetapan hasil penjualan diumumkan tanggal 16 November 2020 dengan total penjualan mencapai 14,91 Miliar rupiah. Dan setelmen diterbitkan tanggal 18 November 2020.(Intan Nirmala Sari, 2020)

Jenis wakaf yang digunakan dalam CWLS ini terdapat dua pilihan yaitu wakaf temporer dan wakaf permanen. Pada wakaf permanen sudah jelas bahwa dana wakaf tidak dapat dikembalikan kepada wakif karena dana tersebut telah menjadi milik umat atau masyarakat, sedangkan wakaf temporer dana wakaf yang telah disetorkan dapat dikembalikan kepada 
pewakif pada saat jatuh tempo. Dasar hukum adanya wakaf sementara (temporer) menurut Imam Abu Hanifah memperbolehkan wakaf temporer karena beliau menyamakan akad wakaf dengan akad pinjam meminjam (ariyah). Dalam kitab Fath al Qodir halaman 73 disebutkan:

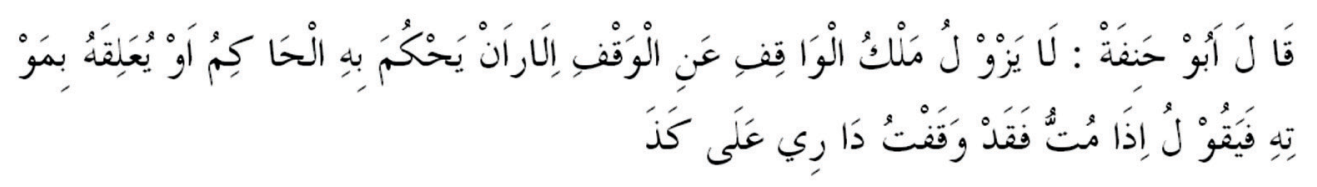

Artinya: "Abu Hanifah berkata: tidak hilang kepemilikan wakif atas hartanya oleh sebab wakaf kecuali adanya keputusan hakim atau ketika sebelum ia meninggal dunia ia mengatakan: "ketika saya meninggal dunia, saya akan mewakafkan rumah saya". (Saptono et al., 2021)

Sebagian wakaf memang tidak terbatas waktu, namun wakaf temporer ini sudah banyak dijalankan. Menurut ulama di negara-negara Organisasi Kerja Sama Islam wakaf temporer diperbolehkan karena dalam hadis Rasul tidak disebutkan waktu untuk berwakaf. Secara fikih, wakaf temporer juga diperbolehkan karena bersifat strategis karena akan mendorong masyarakat untuk berwakaf. Menurut Direktur Pusat Studi Bisnis dan Ekonomi Syariah IPB Bapak Irfan Syauqi Beik dalam suatu forum dikatakan, bahwa wakaf dalam rentang waktu tertentu atau wakaf temporer diperbolehkan, beberapa imam dari mazhab Maliki juga memperbolehkan wakaf termporer.(Republika Online, 2016)

Penerbit CWLS adalah perusahaan penerbit SBSN Indonesia, diikat dengan jenis akad wakalah. CWLS ini berbentuk tanpa warkat dan tidak dapat diperdagangkan di pasar sekunder. Tenor atau jangka waktu CWLS adalah 2 tahun atau akan berakhir pada 10 November 2022. Pemesanan minimum Rp 1 juta dan tidak ada maksimum pemesanan. Imbalannya setara $5.50 \%$ (Fix Coupon) dan pembayarannya secara periodik setiap bulan yaitu setiap tanggal 10. Imbalannya akan diberikan langsung kepada nazhir untuk pembiayaan kegiatan sosial. Underlying Asset dari CWLS ini adalah Barang Milik Negara (BMN) dan proyek atau kegiatan kementerian atau lembaga pada APBN 2020.

Dana penjualan CWLS akan diterima oleh LKS-PWU selaku mitra nazhir pengumpulan sekaligus mitra distribusi SBSN. Setelah dana CWLS terkumpul, 
LKS PWU melakukan pembelian sukuk negara seri CWLS yang dibayarkan kepada Kementerian Keuangan yang selanjutnya melalui Kementerian Keuangan uang hasil penjualan sukuk seri CWLS tersebut akan disalurkan untuk membangun proyek negara. (T. Saptono, 2020) Proyek negara inilah yang disebut underlying asset dari CWLS yang sejak sebelum masa penawaran CWLS, peruntukannya untuk apa saja sudah diketahui dengan jelas.

Pada CWLS ritel, wakif tidak akan menerima imbalan atas investasi melalui CWLS ini melainkan imbalan atau coupon tersebut akan disalurkan melalui nazhir untuk dipergunakan bagi kepentingan penerima manfaat melalui program kegiatan sosial yang telah ditetapkan sebelumnya. (Direktorat Pembiayaan Syariah-Kemenkeu, 2020) Oleh karenanya, niat wakif pada saat melakukan pembelian CWLS ini adalah murni untuk berwakaf dan mengetahui bahwa dana wakafnya akan digunakan untuk membeli sukuk yang imbal hasilnya akan digunakan untuk program/ kegiatan sosial masyarakat, wakif tidak akan menerima imbal hasil dan jika wakaf bersifat temporer maka wakif hanya akan menerima pokoknya saja tanpa ada imbal hasil.

Program sosial yang akan dibiayai dari hasil CWLS akan ditetapkan bersama-sama dengan nazhir, Lembaga Keuangan Syariah Penerima Wakaf Uang (LKSPWU) dan diketahui oleh Pemerintah sebelum masa penawaran. Ini artinya sebelum masa penawaran program sosial yang akan dijalankan apa saja sudah terencana dengan jelas. Alur atau tata cara pembelian CWLS dapat dilihat pada skema di bawah ini:
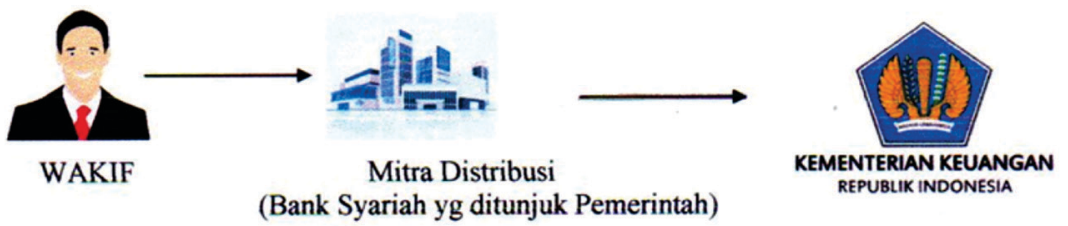
1. Datang ke mitra distribusi untuk melakukan pemesanan CWLS dan menandatangani akta ikrar wakaf
2. Menyetorkan dana wakaf.
1. Pembayaran Imbalan/kupon untuk membiayai program/ kegiatan sosial yang diberikan langsung kepada nazhir melalui mitra distribusi yaitu LKSPWU.
2. Pembayaran nilai nominal saat iatuh tempo.




\section{Peran Cash Waqf Linked Sukuk dalam Program Pemulihan Ekonomi Nasional Akibat COVID-19}

Setelah berakhirnya masa penawaran CWLS pada 20 November 2020, perolehan CWLS mencapai 14,91 Triliun rupiah dengan total 1.041 wakif dari seluruh Indonesia dengan 1.037 wakif perorangan dan 4 wakif institusi. Perlu diketahui dari awal bahwa adanya CWLS ditujukan untuk meningkatkan pertumbuhan ekonomi, memberantas kemiskinan dan meningkatkan produktivitas dana wakaf. Atas imbal hasil atau kupon CWLS ini, salah satu penyalurannya adalah diberikan kepada UMKM untuk modal usaha produktif, itu artinya ada perputaran ekonomi di dalamnya serta meningkatkan produktivitas masyarakat yang tentunya akan meningkatkan pertumbuhan ekonomi di Indonesia. Jika dana wakaf dapat digunakan dengan produktif untuk masyarakat yang membutuhkan, tentu akan berdampak pada peningkatan penghasilan masyarakat dan akan menurunkan angka kemiskinan.

Salah satu urgensi penerbitan CWLS adalah pengembangan investasi sosial di tengah pandemi COVID-19. Program-program sosial yang menjadi fokus CWLS diharapkan dapat turut serta membantu program pemulihan ekonomi nasional. Adanya COVID-19 mengharuskan pemerintah menggunakan APBN untuk penanganan virus ini yan diwujudkan dalam program Pemulihan Ekonomi Nasional, hal ini membuat banyak pembangunan yang tertunda akibat berkurangnya sumber pembiayaan bagi pembangunan nasional.

CWLS merupakan salah satu bentuk Islamic Social Finance yang merupakan terobosan baru dari produk creative financing untuk investasi sosial, CWLS merupakan instrumen pertama di dunia yang bertujuan sebagai mesin pendorong perkembangan potensi wakaf uang di Indonesia. (Putri, Tanjung, \& Hakiem, 2020) CWLS diharapkan dapat menjadi sumber pembiayaan baru, karena sumber pembiayaan ekonomi tidak hanya terbatas pada sektor keuangan komersial, tetapi sektor keuangan sosialpun dapat dioptimalkan, apalagi masyarakat Indonesia memiliki jiwa sosial tertinggi. Jadi, sumber pembiayaan baru ekonomi nasional jika dapat dikelola dengan baik dapat membantu perputaran roda perekonomian. Hal ini sejalan dengan 
tujuan SBSN (Surat Berharga Syariah Nasional) dimana CWLS ini masuk ke dalam salah satu jenis sukuk SBSN.

Banyak masyarakat yang masih meragukan hukum CWLS ini, apakah diperbolehkan atau justru masuk sebagai sesuatu yang dilarang dalam keuangan syariah, atas pertanyaan tersebut masyarakat tidak perlu khawatir karena CWLS ini telah dinyatakan dalam Fatwa dan Pernyaraan Kesesuaian Syariah (Opini Syariah) dari Dewan Syariah Nasional-Majelis Ulama Indonesia (Fatwa DSN MUI No 76/DSN_MUI/IV/2010 tentang SBSN Ijarah Asset to be Leased) dan Fatwa DSN-MUI nomor 95/DSN-MUI/VII/2014 tentang Surat Berharga Syariah Negara (SBSN) Wakalah. (Saptono et al., 2021)

Hasil penjualan CWLS ini akan sangat efektif untuk dijadikan salah satu sumber pembiayaan karena dalam pengelolaannya harta wakaf tidak akan dikenai pajak, selain itu cost of fund atas hasil penjualan CWLS ini adalah nol. CWLS merupakan salah satu bentuk pembiayaan yang sangat murah karena CWLS ini tidak menghendaki pengembalian (kalau bukan temporary wakaf), output yang dihasilkan atas sumber pembiayaan ini akan sangat bagus. Di era pandemi ini adanya CWLS, dana hasil penjualan dapat digunakan oleh pemerintah untuk melaksanakan pembangunan yang terhambat atau tertunda akibat pengalihan APBN untuk pemulihan ekonomi nasional. Hasil imbal jasa dari CWLS inipun akan dikelola untuk membantu masyarakat melalui program-program sosial yang telah direncanakan sebelum terbitnya CWLS ini yang berfokus pada bantuan sosial kepada masyarakat dalam menghadapi pandemi COVID-19. Program-program sosial yang dilakukan dari hasil CWLS ini antara lain:

a. Penyediaan sarana dan pra sarana kesehatan gratis bagi dhuafa. Salah satu rumah sakit yang dananya bersumber dari dana wakaf adalah RS Mata Ahmad Wardi yang salah satu wujudnya adalah pengobatan mata dan operasi katarak gratis.

b. Pembiayaan infrastruktur sosial dan program sosial di daerah, diwujudkan dengan program penjajakan wakaf produktif di Provinsi Riau.

c. Pengembangan Endowment Fund untuk lembaga sosial antara lain Dana Kemaslahatan Badan Pengelola Keuangan Haji (BPKH).

d. Pengembangan dana CSR (Corporate Social Responsibility) untuk kegiatan 
sosial

e. Pemanfaatan lahan nonproduktif baik peternakan maupun perkebunan. Membuat lahan nonproduktif menjadi produktif bukanlah hal yang mudah, dengan adanya dana dari CWLS ini, nazhir dapat dengan mudah membantu masyarakat sekitar untuk memanfaatkan lahan yang produktif untuk dapat dinikmati hasilnya. Jika dalam wujud pertanian maka masyarakat sekitar dapat menikmati hasil kebun untuk kebutuhan pangan sehari-hari. Setelah produktif, lahan-lahan menjadi asset wakaf yang bermanfaat bagi kemaslahatan ummat.

f. Program umrah gratis untuk guru-guru ngaji di daerah.

g. Pemberdayaan UMKM melalui wakaf produktif oleh Rumah Wakaf.

Program sosial yang dilaksanakan dari hasil CWLS ini dilakukan dan dikelola oleh para nazhir yang pengawasannya langsung dilaksanakan oleh BWI. Nazhir yang ditunjuk dalam program CWLS dan beberapa kegiatan sosial yang telah direalisasikan antara lain sebagai berikut:

a. BRI Syariah sebagai LKSPWU dari nazhir NU-CARE LAZISNU dan LAZIS MU. Program yang telah direalisasikan antara lain untuk pemberdayaan UMKM dengan program penyaluran kepada klinik pesantren, beasiswa santri dhuafa dan bantuan modal kerja bagi UMKM, pendayagunaan untuk prgram kesehatan, pembanguna klinik pesantren, dan berbagai macam beasiswa seperti beasiswa mentari, beasiswa sang surya, bakti guru dan save our school.

b. BNI Syariah sebagai LKSPWU dari nazhir Dompet Dhuafa dan Yayasan Hasanah Titik. Program sosial yang direalisasikan antara lain program sosial di bidang ekonomi yaitu untuk Wakaf Hunian Hasanah yaitu program hunian berbiaya murah dengan biaya sewa sekitar Rp 200.000,- Pembangunan ditargetkan 10 rumah dengan target lahan 600 meter persegi. Di bidang kesehatan program yang dilakukan adalah pembiayaan pengobatan pasien dhuafa dan pemberian bantuan pembelian alat pelindung diri untuk tenaga medis sebagai garda terdepan dalam menghadapi COVID-19, sedangkan pada program pendidikan disalurkan pada Khadijah Learning dan beasiswa untuk tunas keluarga Dhuafa. 
c. Bank Muamalat sebagai LKSPWU dari nazhir Baitulmaal Muamalat dan Wakaf Salman ITB. Program sosial yang direalisasikan antara lain di bidang pendidikan yaitu pemberian beasiswa dalam bentuk SPP dan uang saku berkala untuk pengembangan diri baru siswa atau santri tidak mampu dan program beasiswa Cikal dengan total 100 siswa SD dan 200 siswa SMPSMA. Selain itu, dilakukan program pemberian modal kerja bagi UMKM sebesar Rp 3 juta untuk masing-masing UMKM disertai pendampingan dan pelatihan untuk memaksimalkan pengelolaan modal kerja tersebut, sedangkan dalam bidang pembangunan dilakukan pembangunan masjid di Kabupaten Bandung dengan luas lahan $1.400 \mathrm{~m} 2$ dengan total anggaran Rp 1.07 Milyar.

d. Bank Syariah Mandiri sebagai LKSPWU dari nazhir Wakaf BSM Umat dibidang pendidikan yaitu pemberian biaya pendidikan bagi siswa kurang mampu melalui sahabat pelajar Indonesia. Program bantuan kesehatan berupa pemberian bantuan anak tunarungu yaitu pemberian alat bantu dengar bagi tunarungu anak fakir dan miskin berusian 1 bulan-18 tahun. Dalam hal penguatan ketahanan pangan lewat bantuan penangkaran benih padi di Kabupaten Lampung Tengah target sasaran 36 petani dengan luas lahan 10 hektar, selain itu program melalui nazhir Wakaf BSM Umat adalah pemberian bantuan Indukan sapi kepada 50 peternak dengan masing-masing seekor sapi.

Beberapa realisasi program yang dilakukan oleh nazhir di atas memang sangat bermanfaat bagi masyarakat yang membutuhkan sebagai mauquf 'alaih, program yang dilakukan sedikit banyak membantu pemerintah dalam mengentaskan kemiskinan dan kesenjangan sosial dan terutama programprogram sosial yang diberikan kepada masyarakat untuk merangsang kegiatan perekonomian yang lesu akibat pandemi COVID-19.(Mustafida \& Mukhlisin, 2019). Selain bermanfaat bagi pemulihan ekonomi nasional, penyaluran CWLS untuk pembangunan juga dapat menjadikan banyak tanah wakaf yang sebelumnya terbengkalai menjadi tanah wakaf yang produktif. Hal ini dikarenakan dana yang terkumpul dari CWLS dapat digunakan untuk membangun banyak sarana publik yang bermanfaat bagi masyarakat yang didirikan di atas tanah wakaf. (Fauziah \& Tulmafiroh, 2020) 
Mengingat banyak manfaat yang diperoleh dari kegiatan yang didanai dari hasil CWLS ini maka menurut penulis program CWLS ini harus lebih dimaksimalkan lagi pengumpulannya, pengumpulan CWLS ini masih bisa berpotensi memberikan kontribusi yang lebih bagi pembangunan Indonesia jika dana yang terkumpul lebih banyak mengingat wakaf produktif di Indonesia memiliki potensi hingga Rp 200 Triliun dan baru teralisasikan sebesar Rp 400 Milyar. Rendahnya tingkat literasi tentang wakaf menjadi salah satu penghambat realisasi potensi wakaf yang hingga Rp 200 Triliun rupiah tersebut. Oleh karenanya perlu adanya peningkatan kelas literasi zakat dan wakaf oleh Kementerian Agama dan Badan Wakaf Indonesia terutama di era pandemi seperti sekarang ini. Penelitian menunjukkan bahwa literasi masyarakat tentang CWLS masih rendah yaitu ada pada angka 2 dan 3 dari 5 skala (Hiyanti, Fitrijanti, \& Sukmadilaga, 2020). Dalam buku Financing The Development Of Old Waqf Properties Classical Principles And Innovative Practices Around The World disebutkan: Waqf is financial charitable institution established by withholding immovable and movable properties to perpetually spend its revenue on fulfilling public or family needs, depenting on the preferences of and conditions set by the founder. Once the property is creates as waqf, it can never be given as gift, inherited or sold. It belong to Allah (swt) and the waqf property always remains intract. Only its generated revenue is channelled to the beneficiaries. The main motivation for a founder to create waqf is clearly stated in both Quran and the sunnah (Mohsin et al., 2016).

Dari uraian di atas dapat di lihat bahwa atas harta wakaf, pewakiflah yang harus menentukan akan digunakan untuk apa harta yang ia wakafkan. Di Indonesia banyak pewakif yang pemikirannya masih terlalu tradisional dalam memahami wakaf, oleh karenanya BWI harus memberikan sosialisasi bahwa wakaf tidak hanya tentang 3M (Masjid, Mushola, Makam) saja, namun, dapat dimanfaatkan sebagai sesuatu yang leboh produktif dari pada itu. Termasuk dalam hal CWLS ini, hasil atau output yang dihasilkan dari CWLS ini harus disosialisasikan sejak awal akan dipergunakan untuk kegiatan sosial apa saja. Jadi pondasi awal untuk memaksimalkan penjualan CWLS ini adalah sosialisasi kepada calon pewakif yaitu masyarakat. Kemudian dari sisi masyarakat juga harus sadar akan nilai-nilai/ values dari CWLS sebagai salah satu instrumen wakaf produktif yaitu wakaf tidak hanya melepaskan 
aset untuk kepentingan umum saja tapi juga ada nilai keyakinan di dalamnya yaitu yakin bahwa dengan berwakaf akan mendapatkan kebaikan dunia dan akhirat, mindset masyarakat juga harus disamakan yaitu siapapun yg mengelola wakaf harus menciptakan nilai tambah karena sifat wakaf adalah keabadian sehingga harus dikelola dengan produktif agar nilainya tidak berkurang dan bahkan dapat bertambah nilainya. Masyarakat Indonesia harus memiliki karakter memberi bukan menerima atau meminta dan bahwa wakaf adalah prinsip kebersamaan yaitu transformasi saya menjadi kami, kami menjadi kita, bukan saya atau perorangan. (Putri et al., 2020) Untuk menarik minat masyarakat terhadap CWLS dapat dilakukan dengan strategi digitalisasi wakaf uang yang dapat memberikan kemudahan akses bagi wakif sektor pengguna internet.(Zaid Farhand, 2020)

Penelitian yang dilakukan oleh Maghfira Maulidia Putri dankawan kawan pada tahun 2020 tentang strategi implementasi CWLS juga menunjukan hasil yang sama dengan yang dilakukan dalam penelitian ini, bahwa implementasi CWLS di Indonesia masih terhambat dikarenakan beberapa masalah salah satunya adalah nazhir, nazhir dinilai menjadi pemeran utama dalam melakukan pengelolaan CWLS ini, kemudian kurangnya sosialisasi, literasi dan edukasi kepada masyarakat mengenai urgensi CWLS. Oleh karenanya dibutuhkan kerja sama antar regulator atau pihak-pihak yang terlibat langsung dalam pengelolaan CWLS. Strateginya adalah dengan meningkatkan literasi kepada masyarakat, meningkatkan strategi komunikasi dan penghimpunan wakaf melalui media digital dan meningkatkan profesionalitas, transparasi dan akuntabilitas BWI. Ini penting karena CWLS jika dapat dikelola dengan baik dan maksimal akan memberikan bantuan terhadap beban APBN.(Putri et al., 2020)

\section{Simpulan}

Cash Waqf Linked Sukuk merupakan salah satu inovasi baru wakaf produktif yang diluncurkan oleh pemerintah dalam mengembangkan potensi wakaf uang di Indonesia. CWLS merupakan bagian dari SBSN (Surat Berharga Syariah Nasional) yang melalui Kementerian Keuangan diterbitkan oleh pemerintah dengan seri SWR001. Realisasi atau capaian penjualan CWLS mencapai Rp 14, 912 miliar. CWLS di Indonesia melibatkan lima stakehokders 
yaitu Bank Indonesia, Badan Wakaf Indonesia, Kementerian Keuangan, Nazhir Wakaf Produktif, dan Bank kustodian (BNI Syariah, Bank BRI Syariah, Bank Syariah Mandiri dan Bank Muamalat) yang ditunjuk sebagai lembaga keuangan syariah penerima wakaf uang (LKS-PWU) sekaligus Bank Operasional BWI. Peran CWLS dalam program Pemulihan Ekonomi Nasional yaitu dana hasil penjualan CWLS yang terkumpul dapat membantu pemerintah memperoleh sumber pembiayaan baru untuk mengoptimalkan pembangunan nasional yang tertunda akibat pengalokasian APBN yang banyak difokuskan untuk penanganan COVID-19 dan return yang dihasilkan dari CWLS dapat digunakan untuk melaksanakan program sosial untuk masyarakat yang membutuhkan terutama mereka yang kesulitan di bidang ekonomi akibat pandemi COVID-19.

\section{Daftar Rujukan}

AAOIFI. (2003). Standart No. 17: Sharia Standard for Investment Sukuk. Sharia Standard.

Al-Ali, S. (2019). Raising Capital on $\checkmark u k u \bar{k}$ Markets: Structural, Legal and Regulatory Issues. Cham: Springer International Publishing. Retrieved April 6, 2021, from http://link.springer.com/10.1007/978-3-030-14536-1

Bachtiar. (2018). Metode Penelitian Hukum. Tangerang: Unpam Press.

Dhewiyani, R., \& Jaharuddin. (2020). Potensi \& Konsep Wakaf buku \#1. Yogyakarta: Hitam Pustaka.

Direktorat Pembiayaan Syariah, Direktorat Jenderal Pengelolaan Pembiayaan dan Risiko, Kementerian Keuangan Republik Indonesia. (2020, Oktober). Cash Waqf Linked Sukuk Seri SWR001 "Kebaikan Jariyah Penuh Berkah." Jakarta.

Direktorat Pembiayaan Syariah-Kemenkeu. (2020). Frequently Asked Questions (FAQ) Cash Waqf Linked Sukuk (CWLS) Seri SWR001. Direktorat Pembiayaan Syariah Dirjen Pengelolaan Pembiayaan dan Resiko Kementerian Keuangan Republik Indonesia.

Fatwa DSN- MUI No 32/DSN-MUI/IX/2002 Tentang Obligasi Syariah. (2002).

. Dewan Syariah Nasional-Majelis Ulama Indonesia.

Fatwa DSN MUI No 95/DSN-MUI/VII/2014 Tentang SBSN Wakalah. (2014). . Dewan Syariah Nasional-Majelis Ulama Indonesia.

Fatwa DSN -MUI No 137/DSN-MUI/IX/2020 Tentang Sukuk. (2020). . Dewan Syariah Nasional-Majelis Ulama Indonesia. 
Fauziah, N. D., \& Tulmafiroh, A. (2020). Analisis Waqf Linked Sukuk Untuk Memberdayakan Tanah Yang Tidak Produktif. Al-tsaman: Jurnal Ekonomi dan Keuangan Islam, 2(02), 70-81.

Hiyanti, H., Fitrijanti, T., \& Sukmadilaga, C. (2020). PENGARUH LITERASI DAN RELIGIUSITAS TERHADAP INTENSI BERWAKAF PADA CASH WAQF LINKED SUKUK. Jurnal Ilmiah MEA (Manajemen, Ekonomi, E Akuntansi), 4(3), 493-507.

Intan Nirmala Sari. (2020, November). Penjualan CWLS seri SWR001 tembus Rp 14,91 miliar. Konten.co.id. Retrieved April 6, 2021, from https://nasional. kontan.co.id/news/penjualan-cwls-seri-swr001-tembus-rp-1491-miliar

Kacaribu, F. (2020). Live Media Briefing Pemulihan Ekonomi Nasional 1305 - Resep Kuini. Retrieved March 27, 2021, from https://resepkuini.com/ live-media-briefing-pemulihan-ekonomi-nasional-13-05/

Kemenkeu RI. (2020). Covid-19: Dampak, Penanganan, Pemulihan Ekonomi Nasional (Pen), \& Usulan Perubahan Perpres 54 Tahun 2020. Presented at the Media Briefing Kementerian Keuangan Republik Indonesia, Jakarta.

Lahsana, A., Kabir Hassa, M., \& Ahmad, R. (2018). Forward Lease Sukuk in Islamic Capital Markets: Structure and Governing Rules. AC Milan US: Springer International Publishing Palgrave masmillan.

Manan, A. (2016). Hukum Ekonomi Syariah dalam Perspektif Pengadilan Agama. Jakarta: Kencana.

Mohsin, M. I. A., Dafterdar, H., Cizakca, M., Alhabshi, S. O., Razak, S. H. A., Sadr, S. K., Anwar, T., et al. (2016). Financing the Development of Old Waqf Properties. New York: Palgrave Macmillan US. Retrieved March 27, 2021, from http://link.springer.com/10.1057/978-1-137-58128-0

Moleong, L. J. (2018). Metodologi Penelitian Kualitatif. Bandung: PT Remaja Rosdakarya.

Mustafida, R., \& Mukhlisin, M. (2019). Can We Combine Sukuk and Waqf? A Case Study of Indonesia. Revitalization of Waqf for Socio-Economis Development (Vol. I, pp. 169-191). Presented at the Research Workshop on Revival of Waqf for Socio Economic Development, Bangladesh. Retrieved from https://doi.org/10.1007/978-3-030-18445-2_9

Nahar, F. H., Adha, M. A., \& Wardani, D. T. K. (2018). Issues of Sukuk Ijarah. Ihtifaz: Journal of Islamic Economics, Finance, and Banking, 1(1), 21-32.

Nezliani, L. (2020). Analisis Peran Bank Umum Syariah sebagai Potential Investor Untuk Mengoptimalkan Cash Waqf Link Sukuk. Presented at the Annual Conference of Ihtifaz: Islamic Economics, Finance, and Banking, 
Yogyakarta. Retrieved from http://seminar.uad.ac.id/index.php/ihtifaz/ article/view/3630/1012.

Nik Abdul Ghani, N. A. R. (2018). Beneficial ownership in sukuk ijarah: A shari'ah appraisal. International Journal of Islamic and Middle Eastern Finance and Management, 11(1), 2-17.

Pemerintah Republik Indonesia. (2020). PP No 43 Tahun 2020 Tentang Pelaksanaan Program Pemulihan Ekonomi Nasional Dalam Rangka Mendukung Kebijakan Keuangan Negara Untuk Penanganan Pandemi Corona Virus Disease 2019 (Covid-19) dan/atau Menghadapi Ancaman yang Membahayakan Perekonomian Nasional dan/atau Stabilitas Sistem Keuangan Serta Penyelamatan Ekonomi Nasional. Pemerintah Republik Indonesia.

Permatasari, E. (2021). Ulasan lengkap: Mengenal Cash Waqf Linked Sukuk (Sukuk Wakaf). Hukumonline.com/klinik. Retrieved April 19, 2021, from https://www.hukumonline.com/klinik/detail/ulasan/lt6079a118f3c00/ mengenal-i-cash-waqf-linked-sukuk-i-sukuk-wakaf-/

Putri, M. M., Tanjung, H., \& Hakiem, H. (2020). STRATEGI IMPLEMENTASI PENGELOLAAN CASH WAQF LINKED SUKUK DALAM MENDUKUNG PEMBANGUNAN EKONOMI UMAT: PENDEKATAN ANALYTIC NETWORK PROCESS (ANP). Al-Infaq: Jurnal Ekonomi Islam, 11(2), 204-225.

Rahayu, R. D., \& Agustianto, M. A. (2020). Analisis Implementasi Cash Waqf Linked Sukuk (CWLS) Perspektif Prinsip Ekonomi Syariah. Management of Zakat and Waqf Journal (MAZAWA), 1(2), 145-161.

Rahman Ghazaly, A., Ihsan, G., \& Shidiq, S. (2012). Fiqh Muamalat. Jakarta: Kencana.

Republika Online. (2016, November 21). Wakaf Uang Temporal Dinilai Strategis. Republika Online. Retrieved April 20, 2021, from https:// republika.co.id/berita/koran/news-update/16/11/21/ogzcs221-wakafuang-temporal-dinilai-strategis

Safari, M., Ariff, M., \& Mohamad, S. (2019). Sukuk Securities New Ways of Debt Contracting. Singapore: Wiley.

Saptono, I. T., Husna, S., Fahruroji, \& Tanjung, H. (2021). Tanya Jawab Wakaf Uang dan Cash Waqf Linked Sukuk. Jakarta: Badan Wakaf Indonesia.

Soemitra, A. (2009). Bank \& Lembaga Keuangan Syariah. Jakarta: Kencana.

T. Saptono, I. (2020). Wakaf Uang Melalui Instrumen CWLS. Jakarta.

Umar, A., \& Aliyu, S. (2019). Sukuk: A Veritable Tool for Effective Waqf Fund 
Management in Nigeria. IQTISHADIA, 12(1), 1-11.

Undang-Undang Nomor 42 Tahun 2004 Tentang Wakaf. (2004). . Pemerintah Republik Indonesia.

Wahid, N. A. (2010). Memahami \& Membedah Obligasi pada Perbankan Syariah. Yogyakarta: Ar-Ruzz Media.

Zaid Farhand, M. (2020, January). Analisis SWOT terhadap Cash Waqf Linked Sukuk Seri SW001 sebagai Evaluasi Penghimpunan. UIN Syarif Hidayatullah Jakarta, Jakarta. 
Eka Nur Baiti, Syufaat: Cash Waqf Linked Sukuk sebagai Instrumen Pemulihan Ekonomi Nasional Akibat Covid-19 